\title{
Strontium ranelate prevents the deleterious action of advanced glycation endproducts on osteoblastic cells via calcium channel activation.
}

\author{
Juan Manuel Fernández, María Silvina Molinuevo, Claudia Sedlinsky, León Schurman, \\ Ana María Cortizo, Antonio Desmond McCarthy* \\ Laboratorio de Investigación en Osteopatías y Metabolismo Mineral, Facultad de Ciencias Exactas, Universidad Nacional de La Plata. 47 y 115, (1900) La Plata, Argentina
}

\section{A R T I C L E I N F O}

\section{Article history:}

Received 5 October 2012

Received in revised form

15 February 2013

Accepted 24 February 2013

Available online 13 March 2013

Keywords:

Strontium ranelate

Advanced glycation endproducts

Osteoblasts

Calcium channels

$b$-Catenin

Extracellular-regulated kinases

\begin{abstract}
A B S T R A C T
Accumulation of advanced glycation endproducts (AGEs) in bone tissue occurs in ageing and in Diabetes mellitus, and is partly responsible for the increased risk of low-stress bone fractures observed in these conditions. In this study we evaluated whether the anti-osteoporotic agent strontium ranelate can prevent the deleterious effects of AGEs on bone cells, and possible mechanisms of action involved. Using mouse MC3T3E1 osteoblastic cells in culture we evaluated the effects of $0.1 \mathrm{mM}$ strontium ranelate and/or $100 \mu \mathrm{g} / \mathrm{ml}$ AGEs-modified bovine serum albumin (AGEs-BSA) on cell proliferation, osteogenic differentiation and pro-inflammatory cytokine production. We found that AGEs-BSA alone decreased osteoblastic proliferation and differentiation $(P<0.01)$ while increasing IL-1 $\beta$ and TNF $\alpha$ production $(P<0.01)$. On its own, strontium ranelate induced opposite effects: an increase in osteoblast proliferation and differentiation $(P<0.01)$ and a decrease in cytokine secretion $(P<0.01)$. Additionally, strontium ranelate prevented the inhibitory and pro-inflammatory actions of AGEs-BSA on osteoblastic cells $(P<0.01)$. These effects of strontium ranelate were blocked by co-incubation with either the MAPK inhibitor PD98059, or the calcium channel blocker nifedipine. We also evaluated by Western blotting the activation status of ERK (a MAPK) and $b$-catenin. Activation of both signaling pathways was decreased by AGEs treatment, and this inhibitory effect was prevented if AGEs were co-incubated with strontium ranelate $(P<0.01)$. On its own, strontium ranelate increased both pERK and activated $b$-catenin levels. In conclusion, this study demonstrates that strontium ranelate can prevent the deleterious in vitro actions of AGEs on osteoblastic cells in culture by mechanisms that involve calcium channel, MAPK and $b$-catenin activation.
\end{abstract}

(c) 2013 Elsevier B.V. All rights reserved.

\section{Introduction}

Bone is a dynamic tissue that undergoes continuous remodelling throughout the entire life span (Manolagas and Parfitt, 2010). This highly regulated process can be affected by different conditions such as ageing, chronic diseases and pharmacological treatment. In particular, it has been demonstrated that Diabetes mellitus can affect the quality of bone tissue causing an increase in low-stress fractures (Vestergaard et al., 2005), although the exact causes of these alterations are not fully understood. It has been suggested that the accumulation of advanced glycation endproducts as a result of high glucose levels could be an important factor to develop bone alterations (McCarthy et al., 1997; Vlassara and Palace, 2002). We have previously demonstrated that advanced glycation endproducts inhibit osteoblastic proliferation and differentiation (McCarthy et al., 1997, 2001b). The biological effects of advanced glycation

\footnotetext{
* Corresponding author. Tel./fax: + $542214235333 \times 33$.

E-mail addresses: mccarthy@biol.unlp.edu.ar, antoniomccarthy@yahoo.com (A.D. McCarthy).
}

endproducts are mediated by their recognition by specific receptors that in turn induce an increase in receptor expression, activate reactive oxygen species production, mitogen-activated protein kinases and an increase in apoptosis (Alikhani et al., 2007; Gangoiti et al., 2008; McCarthy et al., 2001b; Mercer et al., 2004). Binding of advanced glycation endproducts to these specific receptors can increase the secretion of pro-inflammatory cytokines such as interleukin-6 and tumor necrosis factor- $\alpha$ (TNF $\alpha$ ), which could directly affect bone homeostasis (Bierhaus et al., 2005; Franke et al., 2011; Mosquera, 2010; Takagi et al., 1997). In inflammatory conditions or ageing these cytokines stimulate the expression of RANKL by osteoblasts, thus contributing to the recruitment and activation of osteoclasts that in turn could contribute to bone loss (Franke et al., 2011; Manolagas and Parfitt, 2010; Schett, 2011). We have previously demonstrated that some of these deleterious in vitro actions of advanced glycation endproducts on osteoblasts can be prevented by co-treatment with low doses of potent antiosteoporotic $\mathrm{N}$-containing biphosphonates, as well as by cotreatment with the insulin sensitizer metformin (Gangoiti et al., 2008; Schurman et al., 2008). 
Therapies for patients with osteoporosis include the use of strontium ranelate, which has been reported to induce both anabolic and anti-resorptive effects on bone (Ammann, 2005; Fonseca, 2008; Marie, 2010). It has been demonstrated that strontium ranelate can exert its action in part by activation of the calcium-sensing receptor, which can thus stimulate various intracellular pathways such as extracellular-regulated kinases (ERK), cyclooxigenases, and Wnt signalling (Chattopadhyay et al., 2007; Choudhary et al., 2007). Activation of the calcium-sensing receptor by strontium ranelate induces genes related to osteoblastic growth and maturation (Caverzasio, 2008; Chattopadhyay et al., 2007; Choudhary et al., 2007; Zhu et al., 2007).

In the present work we have evaluated the effects of strontium ranelate on the deleterious action of advanced glycation endproducts on osteoblastic cells in culture of mouse origin. We have also investigated the effect of advanced glycation endproducts and/or strontium ranelate on the activation of calcium channels, extracellular-regulated kinases and $b$-catenin in osteoblastic cells, and on their secretion of proinflammatory cytokines.

\section{Material and methods}

\subsection{Preparation of advanced glycation endproducts}

Advanced glycation endproducts-modified bovine serum albumin was prepared by incubation of $10 \mathrm{mg} / \mathrm{ml}$ bovine serum albumin (bovine serum albumin, Sigma, Argentina) with $33 \mathrm{mM}$ d glycolaldehyde in $150 \mathrm{mM}$ phosphate-buffered saline $\mathrm{pH} 7.4$ at $37{ }^{\circ} \mathrm{C}$ for 3 days under sterile conditions, after which unincorporated sugar was removed (Gangoiti et al., 2008). Control bovine serum albumin was incubated in the same conditions without sugar. The formation of advanced glycation endproducts was assessed with a Shimadzu spectrofluorometer by their characteristic fluorescence-emission maximum at $420 \mathrm{~nm}$ upon excitation at $340 \mathrm{~nm}$. The estimated levels of advanced glycation endproducts-modified bovine serum albumin obtained in this in vitro incubation were $18.5 \%$ relative fluorescence intensity $/ \mathrm{mg}$ protein, in contrast to $3.2 \%$ for control bovine serum albumin.

\subsection{Cell culture and incubations}

MC3T3E1 mouse calvaria-derived cells were grown in Dulbecco's-Eagle's Modified Media (DMEM, LabVet, Argentina) containing $10 \%$ FBS (Natocor, Argentina), $100 \mathrm{U} / \mathrm{ml}$ penicillin and $100 \mu \mathrm{g} /$ $\mathrm{ml}$ streptomycin at $37{ }^{\circ} \mathrm{C}$ in a $5 \% \mathrm{CO}_{2}$ atmosphere (McCarthy et al., 1997). In the non-transformed MC3T3E1 cells, previous studies have demonstrated that expression of osteoblastic markers begins after culturing the cells with medium supplemented by $5 \mathrm{mM}$ $b$-glycerol-phosphate (bGP, Sigma, Argentina) and $145 \mu \mathrm{M}$ ascorbic acid (AA, Sigma, Argentina) (Quarles et al., 1992). For proliferation and differentiation experiments, cells seeded on multiwell plates were incubated in DMEM medium with different doses of control bovine serum albumin or advanced glycation endproducts-modified bovine serum albumin, with or without strontium ranelate (kindly provided by Servier, Argentina), and in the presence or absence of Nifedipine or PD98059, for the periods of time indicated in the legends of figures. For ALP expression and type I collagen production experiments with MC3T3E1 osteoblasts, cells were cultured for 1 week in DMEM/Fetal bovine serum supplemented with bGP and AA changing the medium every 2 days, after which the differentiation medium was changed and cells were incubated with different doses of non glycated- bovine serum albumin or advanced glycation endproductsmodified bovine serum albumin, with or without strontium ranelate, for an additional $72 \mathrm{~h}$.

\subsection{Cell proliferation assay}

Cell proliferation was determined using the crystal violet (Sigma, Argentina) mitogenic bioassay as described previously (Gangoiti et al., 2008). Briefly, cells were incubated with different concentrations of strontium ranelate in serum-free DMEM, according to the figure legends. Then, the monolayers were fixed with $5 \%$ glutaraldehyde, stained with $0.5 \%$ crystal violet $/ 25 \%$ methanol and the dye taken up by the cells was extracted using $0.5 \mathrm{ml} /$ well $0.1 \mathrm{M}$ glycine/ $\mathrm{HCl}$ buffer, $\mathrm{pH}$ 3.0/30\% methanol. Absorbance was read at $540 \mathrm{~nm}$ after a convenient sample dilution.

\subsection{Assays for osteoblastic differentiation}

Osteoblastic differentiation was evaluated by two markers: ALP and the quantitation of type I collagen production, as we have previously described (Molinuevo et al., 2010). Cells were washed with PBS and solubilised in $0.5 \mathrm{ml} 0.1 \%$ Triton X-100. Aliquots of the total cell extract were used for colorimetric protein determination (Bradford, 1976). Measurement of ALP was carried out by spectrophotometric determination at $405 \mathrm{~nm}$ of hydrolysis of paranitrophenyl-phosphate (Sigma, Argentina) to para-nitrophenol (pNP) at $37^{\circ} \mathrm{C}$ for $10 \mathrm{~min}$. Under the same experimental conditions, collagen production was evaluated with a Sirius red-based colorimetric micro-assay (Molinuevo et al., 2010): cells were fixed in Bouin's fluid for $1 \mathrm{~h}$, washed with water and stained with Sirius Red (Sigma, Argentina) dye for $1 \mathrm{~h}$. The stained material was dissolved in $0.1 \mathrm{~N}$ sodium hydroxide and absorbance read at $550 \mathrm{~nm}$.

\subsection{Western blot analysis of pERK and b-catenin}

In these experiments, osteoblastic cells growing in serum-free medium with the addition of different concentrations of strontium ranelate with or without $10 \mu \mathrm{M}$ nifedipine were lysated in Laemmli et al. (1976) and the protein content was evaluated by the method of Lowry et al. (1951). These lysates were heated at $100{ }^{\circ} \mathrm{C}$ for $3 \mathrm{~min}$ and aliquots corresponding to $30 \mu \mathrm{g}$ of total protein were subjected to $12 \%$ SDS-PAGE. After washing and blocking, the membranes were incubated either with an anti-pERK antibody (Santa Cruz, Argentina), with a polyclonal antibody that recognizes phosphorylated isoform of ERK, or with an anti-actin antibody; or with antibodies against either the active isoform of $b$-catenin or total $b$-catenin (Micropore). The intensity of the specific bands was quantified by densitometry after scanning of the membranes. Images were analysed using the gels plugin of MBF_Image J (http://www.macbiophotonics.ca).

\subsection{ELISA assay for interleukin $1 b$ and tumour necrosis factor $a$}

Osteoblastic cells were incubated during $24 \mathrm{~h}$ with either control bovine serum albumin or advanced glycation endproducts-modified albumin, with or without strontium ranelate, and in the presence or absence of $10 \mu \mathrm{M}$ nifedipine. Interleukin $1-\beta$ (IL-1 $\beta$ ) and tumor necrosis factor- $\alpha$ (TNF $\alpha$ ) were evaluated in the conditioned media with a commercial ELISA kit (Mouse IL- $1 \beta$ ELISA Kit, OptEIA ${ }^{\mathrm{TM}}$ from BD Biosciences and Mouse TNF- $\alpha$ ELISA Kit, OptEIA ${ }^{\mathrm{TM}}$ ) using 3,3',5,5'-tetrametilbenzidine from BD Biosciences kit as a chromogenic substrate (Cortizo et al., 2012).

\subsection{Statistical analysis}

Three independent experiments were run for each experimental condition. Results are expressed as the mean \pm S.E.M. One Way ANOVA with Dunnett's post test was performed using GraphPad InStat version 3.05.GraphPad Software, San Diego, California USA; $P<0.05$ was considered to be statistically significant when compared with untreated control ( $0 \mu \mathrm{M}$ strontium ranelate). 


\section{Results}

\subsection{Effect of advanced glycation endproducts and strontium ranelate on osteoblastic cell proliferation}

Since strontium ranelate has been shown to exert an anabolic effect on bone tissue (Marie, 2010), we evaluated its effect on MC3T3E1 osteoblastic cell growth. In our experimental conditions, strontium ranelate dose-dependently increased osteoblastic cell proliferation (Fig. 1A).

We found opposite results for glycated albumin: namely, that 100 and $200 \mu \mathrm{g} / \mathrm{ml}$ advanced glycation endproducts-modified albumin significantly inhibited MC3T3E1 cell proliferation when compared with non-glycated bovine serum albumin (Fig. 1B). In view of the opposing effects observed, we next evaluated whether strontium ranelate could prevent the anti-proliferative action of advanced glycation endproducts in this cell line. In co-incubation experiments, we found that $0.1 \mathrm{mM}$ strontium ranelate was able to prevent the deleterious action of advanced glycation endproducts (Fig. 1B). The choice of this concentration of strontium ranelate is especielly relevant, since it coincides with the dose of the drug that has been found in the serum of post-menopausal women treated with strontium ranelate (Marie, 2008).

\subsection{Action of advanced glycation endproducts and strontium} ranelate on osteoblastic differentiation. role of calcium channels and extracellular signal-regulated kinases

In further experiments we investigated the effect of strontium ranelate and/or advanced glycation endproducts on osteoblastic differentiation, namely cell-associated collagen production and ALP activity. Advanced glycation endproducts $(100 \mu \mathrm{g} / \mathrm{ml})$ inhibited osteoblastic differentiation (Fig. 1C and D). On the other hand, we found that $0.1 \mathrm{mM}$ strontium ranelate increased both type I collagen production (Fig. 1C) and ALP activity (Fig. 1D) when compared to control bovine serum albumin $(100 \mu \mathrm{g} / \mathrm{ml})$. Moreover, $0.1 \mathrm{mM}$ strontium ranelate significantly prevented the inhibition of osteoblastic differentiation caused by advanced glycation endproducts (Fig. 1C and D).

It has been proposed that the action of strontium ranelate is mediated by the activation of calcium channels (Caverzasio, 2008). We found that $10 \mu \mathrm{M}$ nifedipine was able to block the increase of type I collagen and ALP activity induced by $0.1 \mathrm{mM}$ of strontium ranelate compared to control condition (bovine serum albumin) (Fig. 2A and B). Similarly, the co-incubation of nifedipine with strontium ranelate and advanced glycation endproducts blunted the increase of differentiation parameters induced by strontium ranelate (Fig. 2A and B).

In another series of experiments, we found that strontium ranelate-induced type I collagen production was mediated by ERK pathway, since this effect could be blocked by co-incubation with $0.5 \mu \mathrm{M}$ PD98059 (Fig. 2C). As already mentioned, advanced glycation endproducts induced a decrease in type I collagen production, an action that was prevented by co-incubation with $0.1 \mathrm{mM}$ strontium ranelate. This preventive effect of strontium ranelate could also be blocked by incubation with PD98059 (Fig. 2C).

When we investigated the activation of ERK by Western blot analysis, we found that $0.1 \mathrm{mM}$ strontium ranelate induced the activation of ERK compared to bovine serum albumin (Fig. 3),
A
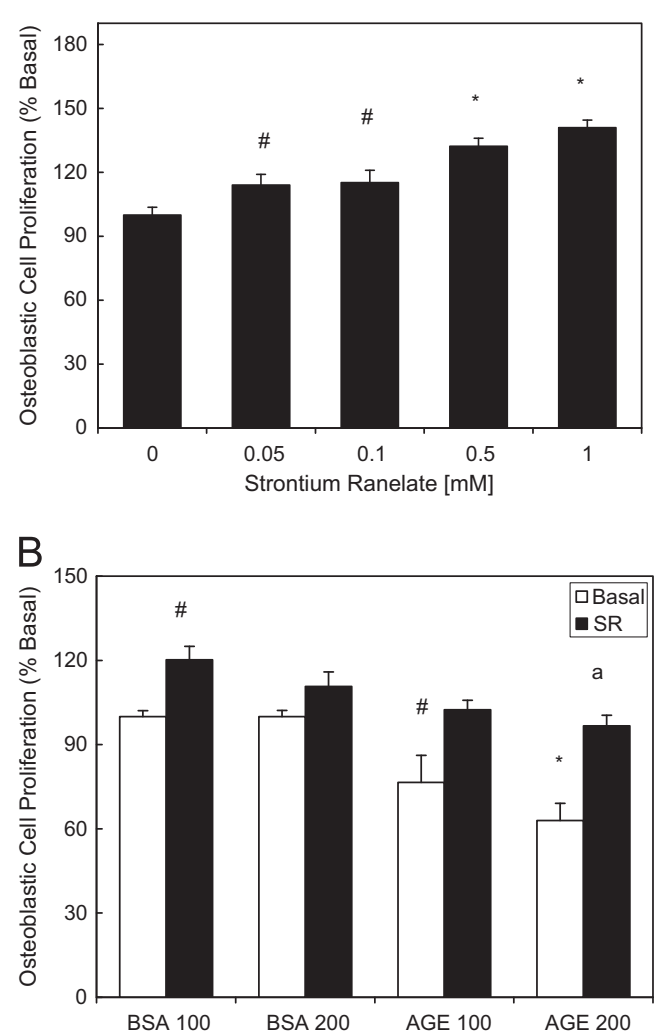

C
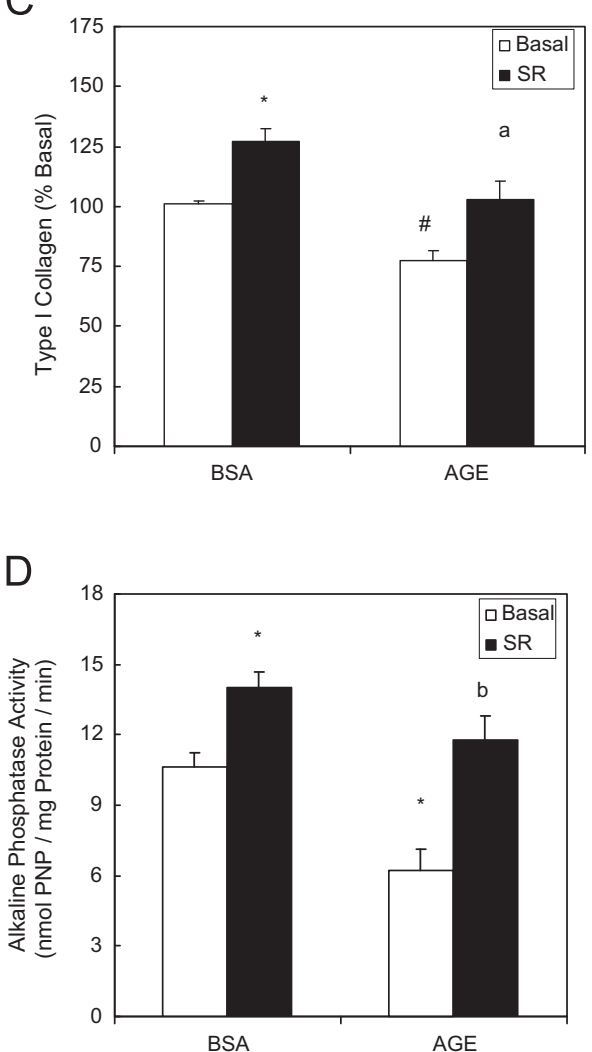

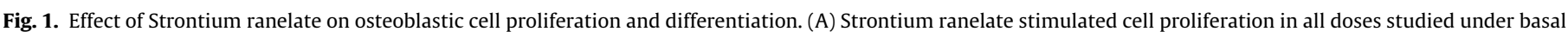

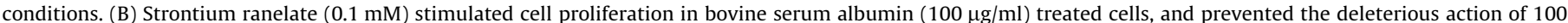

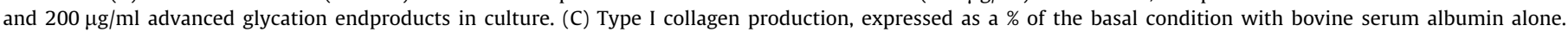

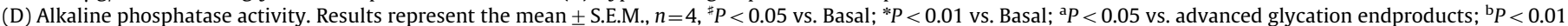
vs. advanced glycation endproducts. SR: Strontium ranelate. AGE: advanced glycation endproducts-modified bovine serum albumin. BSA: bovine serum albumin. 
A

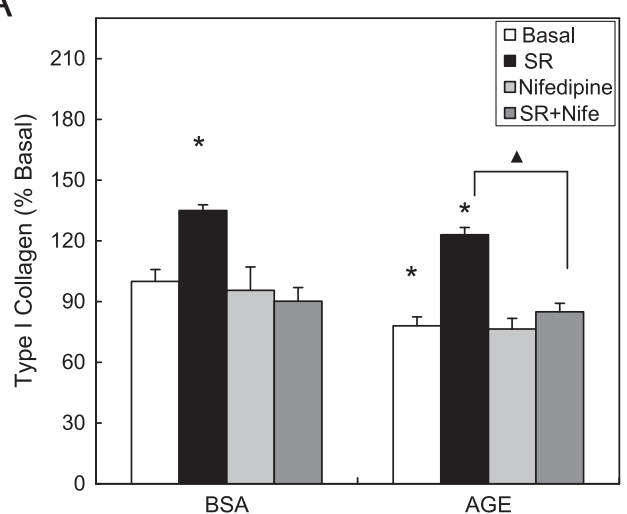

B
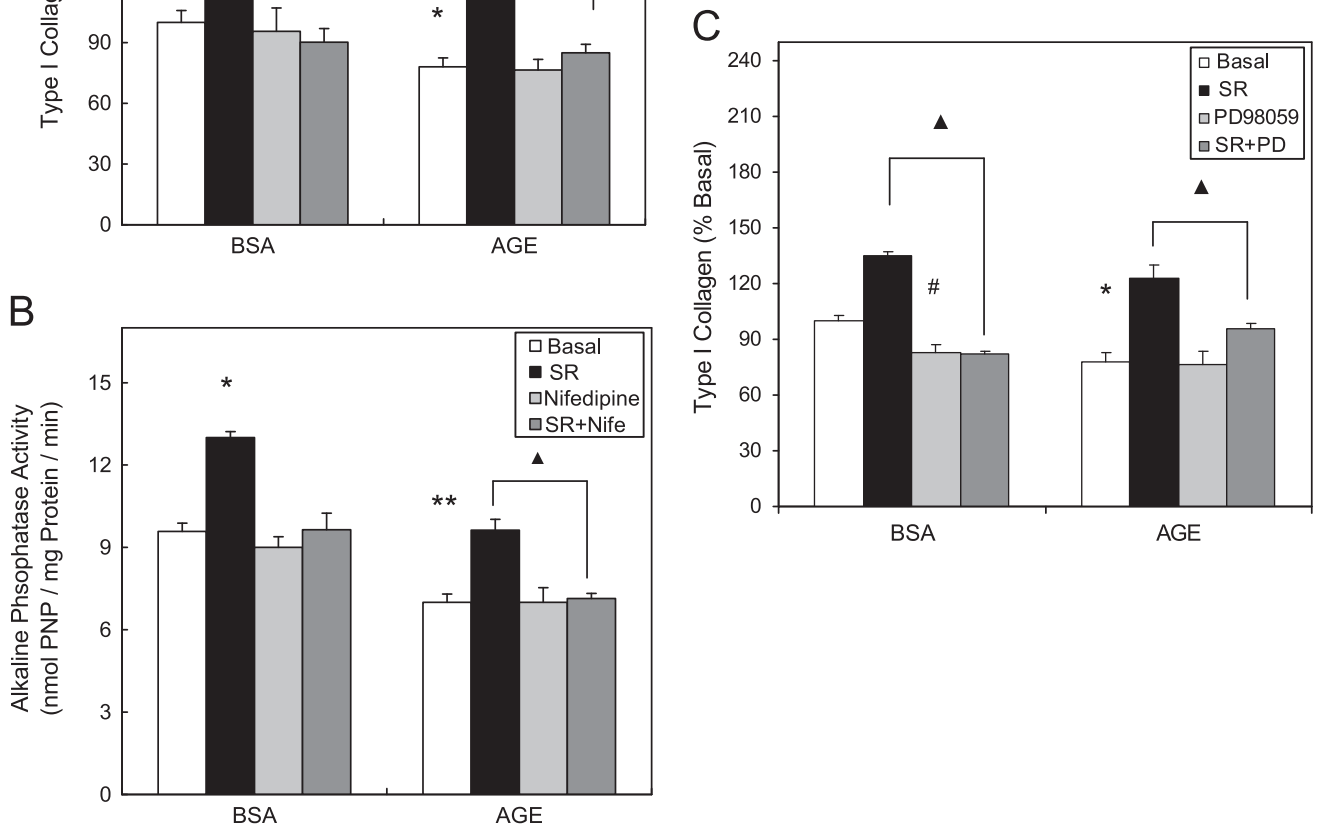

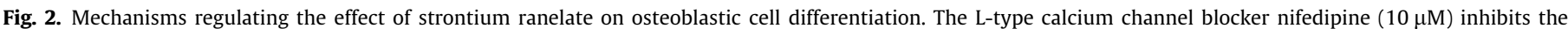

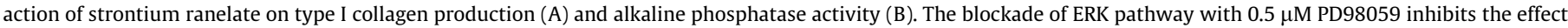

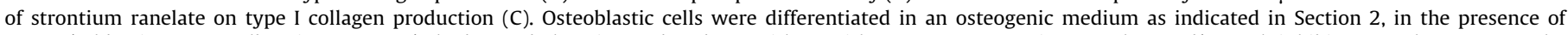

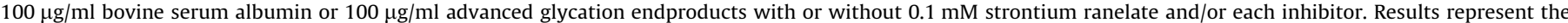

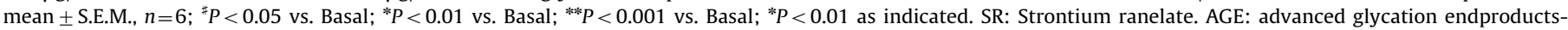
modified bovine serum albumin. BSA: bovine serum albumin.

while advanced glycation endproducts inhibited this pathway. The co-incubation of advanced glycation endproducts with strontium ranelate increased the activation of ERK to levels similar to those with strontium ranelate alone (Fig. 3). In addition, we demonstrated that these effects were mediated by calcium channels since $10 \mu \mathrm{M}$ nifedipine was able to abolish the strontium ranelate-induced activation of ERK, both in the presence or absence of advanced glycation endproducts (Fig. 3 ).

\subsection{Actions of strontium ranelate, advanced glycation endproducts and nifedipine on b-catenin activation}

In order to evaluate the Wnt pathway we investigated the activation of its downstream mediator $b$-catenin. We found that $0.1 \mathrm{mM}$ strontium ranelate stimulated $b$-catenin activation (Fig. 4). On the contrary, advanced glycation endproducts significantly inhibited $b$-catenin activation, an effect that was prevented by co-incubation with $0.1 \mathrm{mM}$ strontium ranelate (Fig. 4). All these effects of strontium ranelate (alone or with advanced glycation endproducts) on $b$-catenin activation were inhibited by $10 \mu \mathrm{M}$ nifedipine (Fig. 4).

\subsection{Modulation of cytokine secretion by strontium ranelate and advanced glycation endproducts}

We also investigated possible changes in the osteoblastic secretion to culture media of IL- $1 \beta$ and TNF $\alpha$, induced by different experimental conditions. In control conditions $(100 \mu \mathrm{g} / \mathrm{ml}$ bovine serum albumin) strontium ranelate significantly inhibited both
IL-1 $\beta$ and TNF $\alpha$ secretion (Fig. 5A and B, respectively). We also found that $100 \mu \mathrm{g} / \mathrm{ml}$ advanced glycation endproducts significantly increased the secretion of IL- $1 \beta$ (Fig. 5A) and TNF $\alpha$ (Fig. 5B) to the culture media when compared with bovine serum albumin. This increase in the secretion of both interleukins caused by advanced glycation endproducts was completely abolished by co-incubation with $0.1 \mathrm{mM}$ strontium ranelate (Fig. 5A and B). The preventive action of strontium ranelate on the increase of IL$1 \beta$ and TNF $\alpha$ secretion induced by advanced glycation endproducts was partially blocked by co-treatment with $10 \mu \mathrm{M}$ nifedipine (Fig. 5A and B). However, nifedipine treatment with either bovine serum albumin or advanced glycation endproducts (i.e, without strontium ranelate) induced no effect on the secretion of IL-1 $\beta$ (Fig. 5A), and only partially inhibited the secretion of TNF $\alpha$ induced by advanced glycation endproducts (Fig. 5B).

\section{Discussion}

Bone is a metabolically active tissue that is constantly remodeled throughout the entire lifespan, in a dynamic and tightly coupled process involving bone formation by osteoblasts and bone resorption by osteoclasts. This process can be modulated by different hormones and cytokines that induce or inhibit bone formation and/ or resorption (Kwan Tat et al., 2004; Lambert et al., 2007) It has previously been demonstrated that bone turnover in diabetic patients is altered, causing an increase in bone fragility and as a consequence an increase in fracture incidence (Krakauer et al., 1995; Vestergaard et al., 2005). The reasons for this alteration are unclear, 

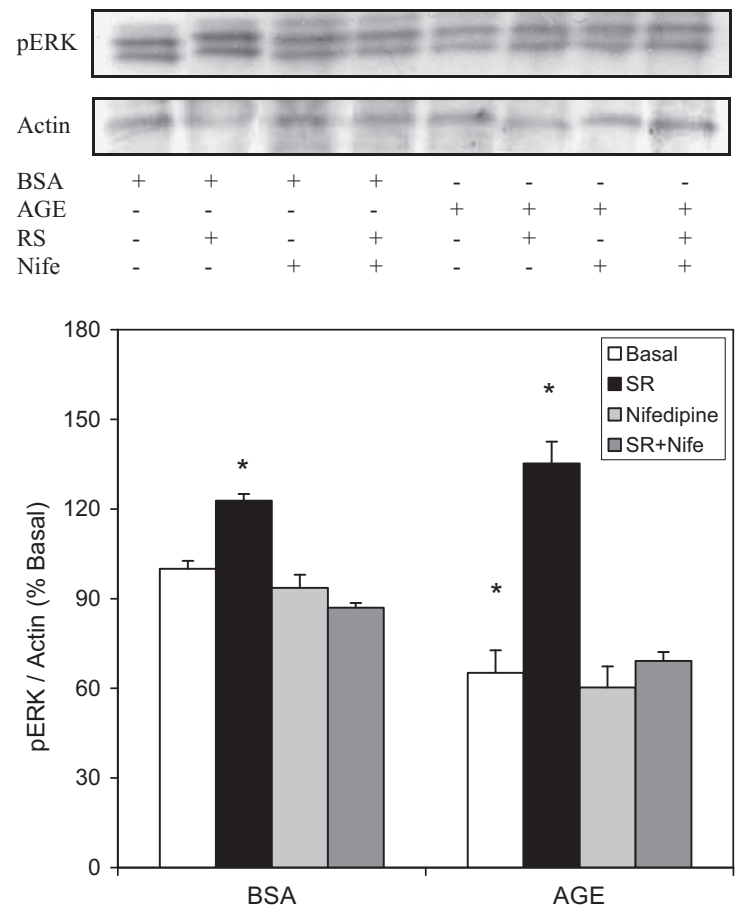

Fig. 3. Strontium ranelate increases pERK levels through the activation of calcium channels. Osteoblastic cells were treated with $100 \mu \mathrm{g} / \mathrm{ml}$ bovine serum albumin or $100 \mu \mathrm{g} / \mathrm{ml}$ advanced glycation-end products with or without strontium ranelate and/or $10 \mu \mathrm{M}$ nifedipine for $1 \mathrm{~h}$ and pERK levels were analyzed by Western blot. Results are expressed as a \% of the basal condition (bovine serum albumin) and represent the mean \pm S.E.M., $n=4 ;{ }^{*} P<0.01$ vs. Basal. SR: Strontium ranelate. AGE: advanced glycation endproducts-modified bovine serum albumin. BSA: bovine serum albumin.
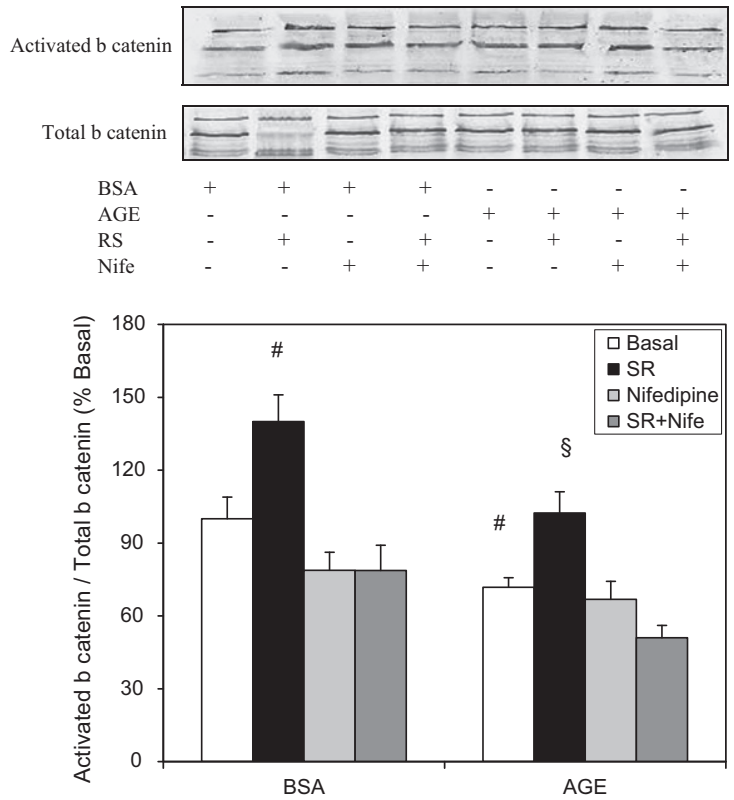

Fig. 4. Prevention by strontium ranelate of advanced glycation endproducts inhibition of $b$-catenin activation. This effect of strontium ranelate is abolished by co-incubation with $10 \mu \mathrm{M}$ nifedipine. Results are expressed as a \% of the basal condition (bovine serum albumin) and represent the mean \pm S.E.M., $n=4$; ${ }^{\sharp} P<0.05$ vs. Basal; ${ }^{\S} P<0.01$ vs. advanced glycation endproducts. SR: Strontium ranelate. AGE: advanced glycation endproducts-modified bovine serum albumin. BSA: bovine serum albumin.

however epidemiological and research data indicate that one of the causes could be the accumulation of advanced glycation endproducts on the organic matrix of bone, mainly type 1 collagen
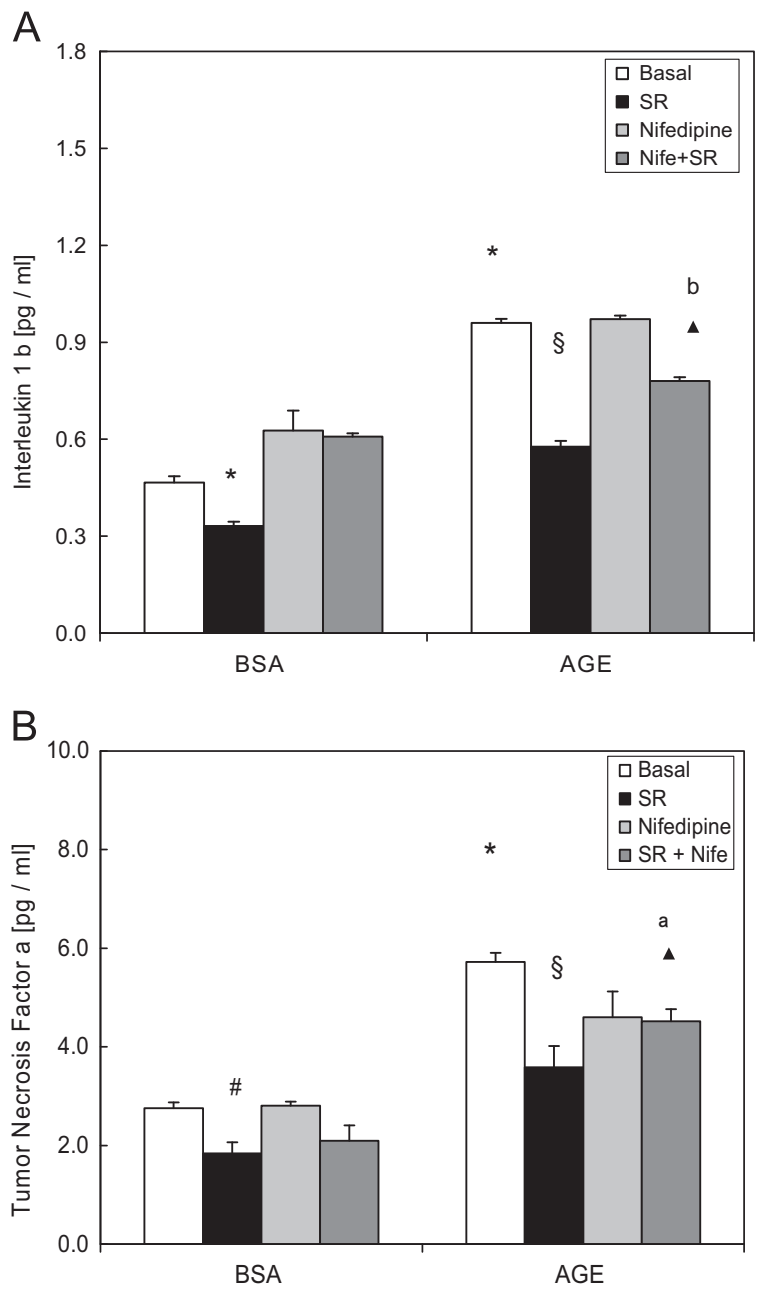

Fig. 5. Strontium ranelate inhibits cytokine production induced by advanced glycation endproducts. This effect is dependent on the activation of L-type calcium channels. (A) IL-1 $\beta$ production and (B) TNF $\alpha$ production. Results represent the mean \pm S.E.M., $n=4 ;{ }^{\sharp} P<0.05$ vs. Basal; ${ }^{*} P<0.01$ vs. Basal; ${ }^{\circledR} P<0.01$ vs. advanced glycation endproducts; ${ }^{*} P<0.05$ vs. advanced glycation endproducts; ${ }^{a} P<0.05$ vs. AGE + SR; ${ }^{b} P<0.01$ vs. AGE + SR. SR: Strontium ranelate. AGE: advanced glycation endproducts-modified bovine serum albumin. BSA: bovine serum albumin.

(McCarthy et al., 2001a; Wongdee and Charoenphandhu, 2011). We have previously demonstrated that glycated collagen impairs osteoblastic attachment, spreading, maturation and mineralising capacity (McCarthy et al., 1997, 2001a', 1999). We have also demonstrated that soluble proteins such as albumin modified by advanced glycation endproducts, can inhibit osteoblastic cell proliferation and differentiation (McCarthy et al., 1997) and that this deleterious action of advanced glycation endproducts on osteoblasts can be prevented by different insulin-sensitizing or anti-resorptive agents (Gangoiti et al., 2008; Schurman et al., 2008). In the present work we have evaluated possible effects on osteoblastic cells in culture, of the anti-osteoporotic agent strontium ranelate, alone or in combination with advanced glycation endproducts. In line with the findings of other authors (Fonseca, 2008; Marie, 2010), our present results confirm that strontium ranelate on its own can act as an anabolic agent on osteoblastic cells in culture, inducing their proliferation and differentiation. In addition, we have found that strontium ranelate is able to prevent the deleterious action of advanced glycation endproducts on the proliferation, alkaline phosphatase activity and type-1collagen production of osteoblastlike cells in culture. Our results indicate that these preventive effects of strontium ranelate are mediated by the activation of calcium 
channels and, as a consequence, the activation of ERK and $b$-catenin. Consistent with our results, other authors have proposed that the anabolic action of strontium ranelate on osteoblasts is mediated by the activation of ERK as well as Wnt pathway (Brown, 2003; Fromigue et al., 2009; Marie, 2010).

Calcium is an abundant cation that is utilized for signal transduction in most cell types. L-type calcium channels have been shown to be highly expressed and physiologically active in osteoblasts. Activation of these channels leads to an increase in intracellular calcium levels, and this has been associated with increased survival and functionality of osteoblasts (Blair et al., 2007). Strontium ranelate has previously been demonstrated to modulate intracellular calcium levels, via calcium sensor receptor-dependent and independent pathways. Our present results are in agreement with these proposed mechanisms: we show that strontium ranelate blocks the deleterious action of advanced glycation endproducts on osteoblastic cells by activating L-type calcium channels, and thus modulating the activation of ERK and $b$-catenin.

Bone metabolic balance can be controlled by different cytokines; some of them favour osteoblastic bone formation while others promote bone resorption (Kwan Tat et al., 2004; Lambert et al., 2007). In physiological or pathological conditions that induce a systemic accumulation of advanced glycation endproducts (ageing, Diabetes mellitus, renal insufficiency, chronic intake of excess dietary advanced glycation endproducts), there is an increase in circulating pro-inflammatory cytokines such as TNF $\alpha$ and IL-1 $\beta$ (Vlassara and Striker, 2011). These cytokines have previously been found to induce osteoclastic development while decreasing osteoblast activity and function (Kwan Tat et al., 2004; Wongdee and Charoenphandhu, 2011), and so their imbalance over a prolonged period of time could contribute to the development of bone alterations. In the present study we have found that strontium ranelate decreased the osteoblastic secretion of IL-1 $\beta$ and TNF $\alpha$. These results are in agreement with those of Boanini et al. who found that strontium was able to decrease IL6 production by osteoblasts (Boanini et al., 2011). It has previously been demontrated that IL1 $\beta$, IL6 and TNF $\alpha$ can control and influence the expression of each other, and also synergistically stimulate osteoblastic production of pro-osteoclastic factors such as RANKL (Kwan Tat et al., 2004). In the present study, we have found that advanced glycation endproducts increase the secretion of TNF $\alpha$ and IL- $1 \beta$ by cultured osteoblastic cells, while co-incubation with strontium ranelate prevents this increase.

In conclusion, we have demonstrated that strontium ranelate can prevent the deleterious actions of advanced glycation endproducts on osteoblastic cells in culture. The mechanisms of action involved include activation of L-type calcium channels, upstream to the activation of ERK and $b$-catenin. On its own, strontium ranelate decreases the osteoblastic secretion of proinflammatory and pro-osteoclastic cytokines TNF $\alpha$ and IL-1 $\beta$, suggesting that in addition to its anabolic effect on bone it could also have anti-catabolic actions. Our in vitro results thus suggest that strontium ranelate could be an interesting option for the treatment of low bone mass and/or increased bone fragility in conditions associated with an accumulation of advanced glycation endproducts, due to its potential preventive effects on advanced glycation endproducts-induced bone alterations, as well as its combined anabolic and anti-catabolic effects.

\section{Declaration of interest}

LS has received lecture fees from Servier. None of the other authors have conflicts of interest.

\section{Funding}

This work was partially supported by grants from Facultad de Ciencias Exactas, Universidad Nacional de La Plata (UNLP), Comisión de Investigaciones Científicas de la Provincia de Buenos Aires (CICPBA), Agencia Nacional de Promoción Científica y Tecnológica (PICT 1083 BID-1728/OC-AR) and Consejo Nacional de Investigación Científica y Tecnológica (PIP-0035).

\section{Author contributions}

All the authors contributed equally to the present work.

\section{Acknowledgements}

JMF is Postdoctoral Fellow of CONICET, Argentina. MSM is Investigador Adjunto of CONICET, Argentina. AMC is Investigador Principal of CICPBA, Argentina. ADM is a part-time Researcher and Professor of UNLP.

\section{References}

Alikhani, M., Alikhani, Z., Boyd, C., MacLellan, C.M., Raptis, M., Liu, R., Pischon, N. Trackman, P.C., Gerstenfeld, L., Graves, D.T., 2007. Advanced glycation end products stimulate osteoblast apoptosis via the MAP kinase and cytosolic apoptotic pathways. Bone 40, 345-353.

Ammann, P., 2005. Strontium ranelate: a novel mode of action leading to renewed bone quality. Osteoporos. Int. 16 (Suppl. 1), S11-15.

Bierhaus, A., Humpert, P.M., Stern, D.M., Arnold, B., Nawroth, P.P., 2005. Advanced glycation end product receptor-mediated cellular dysfunction. Ann. N.Y. Acad. Sci. 1043, 676-680.

Blair, H.C., Schlesinger, P.H., Huang, C.L., Zaidi, M., 2007. Calcium signalling and calcium transport in bone disease. Subcell. Biochem 45, 539-562.

Boanini, E., Torricelli, P., Fini, M., Bigi, A., 2011. Osteopenic bone cell response to strontium-substituted hydroxyapatite. J. Mater. Sci.-Mater. Med. 22 2079-2088.

Bradford, M.M., 1976. A rapid and sensitive method for the quantitation of microgram quantities of protein utilizing the principle of protein-dye binding. Anal. Biochem. 72, 248-254.

Brown, E.M., 2003. Is the calcium receptor a molecular target for the actions of strontium on bone? Osteoporos. Int. 14 (Suppl. 3), S25-34.

Caverzasio, J., 2008. Strontium ranelate promotes osteoblastic cell replication through at least two different mechanisms. Bone 42, 1131-1136.

Cortizo, A.M., Ruderman, G., Correa, G., Mogilner, I.G., Tolosa, E.J., 2012. Effect of surface topography of collagen scaffolds on cytotoxicity and osteoblast differentiation. J. Biomater. Tissue Eng., 2.

Chattopadhyay, N., Quinn, S.J., Kifor, O., Ye, C., Brown, E.M., 2007. The calciumsensing receptor $(\mathrm{CaR})$ is involved in strontium ranelate-induced osteoblast proliferation. Biochem. Pharmacol. 74, 438-447.

Choudhary, S., Halbout, P., Alander, C., Raisz, L., Pilbeam, C., 2007. Strontium ranelate promotes osteoblastic differentiation and mineralization of murine bone marrow stromal cells: involvement of prostaglandins. J. Bone Miner. Res. 22, 1002-1010.

Fonseca, J.E., 2008. Rebalancing bone turnover in favour of formation with strontium ranelate: implications for bone strength. Rheumatology (Oxford) 47 (Suppl. 4), iv17-19.

Franke, S., Ruster, C., Pester, J., Hofmann, G., Oelzner, P., Wolf, G., 2011. Advanced glycation end products affect growth and function of osteoblasts. Clin. Exp. Rheumatol. 29, 650-660.

Fromigue, O., Hay, E., Barbara, A., Petrel, C., Traiffort, E., Ruat, M., Marie, P.J., 2009 Calcium sensing receptor-dependent and receptor-independent activation of osteoblast replication and survival by strontium ranelate. J. Cell. Mol. Med. 13 2189-2199.

Gangoiti, M.V., Cortizo, A.M., Arnol, V., Felice, J.I., McCarthy, A.D., 2008. Opposing effects of bisphosphonates and advanced glycation end-products on osteoblastic cells. Eur. J. Pharmacol. 600, 140-147.

Krakauer, J.C., McKenna, M.J., Buderer, N.F., Rao, D.S., Whitehouse, F.W., Parfitt, A.M., 1995. Bone loss and bone turnover in diabetes. Diabetes $44,775-782$.

Kwan Tat, S., Padrines, M., Theoleyre, S., Heymann, D., Fortun, Y., 2004. IL-6, RANKL, TNF- $\alpha /$ IL-1: interrelations in bone resorption pathophysiology. Cytokine Growth Factor Rev. 15, 49-60.

Laemmli, U.K., Amos, L.A., Klug, A., 1976. Correlation between structural transformation and cleavage of the major head protein of T4 bacteriophage. Cell 7 191-203.

Lambert, C., Oury, C., Dejardin, E., Chariot, A., Piette, J., Malaise, M., Merville, M.P. Franchimont, N., 2007. Further insights in the mechanisms of interleukin-1 $\beta$ 
stimulation of osteoprotegerin in osteoblast-like cells. J. Bone Miner. Res. 22, $1350-1361$.

Lowry, O.H., Rosebrough, N.J., Farr, A.L., Randall, R.J., 1951. Protein measurement with the Folin phenol reagent. J. Biol. Chem. 193, 265-275.

Manolagas, S.C., Parfitt, A.M., 2010. What old means to bone. Trends Endocrinol. Metab. 21, 369-374.

Marie, P.J., 2008. Effective doses for strontium ranelate. Osteoporos. Int.19 (1813), 1815-1817author reply.

Marie, P.J., 2010. Strontium ranelate in osteoporosis and beyond: identifying molecular targets in bone cell biology. Mol. Interv. 10, 305-312.

McCarthy, A.D., Etcheverry, S.B., Bruzzone, L., Cortizo, A.M., 1997. Effects of advanced glycation end-products on the proliferation and differentiation of osteoblast-like cells. Mol. Cell. Biochem. 170, 43-51.

McCarthy, A.D., Etcheverry, S.B., Bruzzone, L., Lettieri, G., Barrio, D.A., Cortizo, A.M., 2001a. Non-enzymatic glycosylation of a type I collagen matrix: effects on osteoblastic development and oxidative stress. BMC Cell Biol. 2, 16.

McCarthy, A.D., Etcheverry, S.B., Cortizo, A.M., 1999. Advanced glycation endproduct-specific receptors in rat and mouse osteoblast-like cells: regulation with stages of differentiation. Acta Diabetol. 36, 45-52.

McCarthy, A.D., Etcheverry, S.B., Cortizo, A.M., 2001b. Effect of advanced glycation endproducts on the secretion of insulin-like growth factor-I and its binding proteins: role in osteoblast development. Acta Diabetol. 38, 113-122.

Mercer, N., Ahmed, H., McCarthy, A.D., Etcheverry, S.B., Vasta, G.R., Cortizo, A.M. 2004. AGE-R3/galectin-3 expression in osteoblast-like cells: regulation by AGEs. Mol. Cell. Biochem. 266, 17-24.

Molinuevo, M.S., Schurman, L., McCarthy, A.D., Cortizo, A.M., Tolosa, M.J., Gangoiti, M.V., Arnol, V., Sedlinsky, C., 2010. Effect of metformin on bone marrow progenitor cell differentiation: in vivo and in vitro studies. J. Bone Miner. Res. $25,211-221$.
Mosquera, J.A., 2010. Role of the receptor for advanced glycation end products (RAGE) in inflammation. Invest. Clin. 51, 257-268.

Quarles, L.D., Yohay, D.A., Lever, L.W., Caton, R., Wenstrup, R.J., 1992. Distinct proliferative and differentiated stages of murine MC3T3-E1 cells in culture: an in vitro model of osteoblast development. J. Bone Miner. Res. 7, 683-692.

Schett, G., 2011. Effects of inflammatory and anti-inflammatory cytokines on the bone. Eur. J. Clin. Invest. 41, 1361-1366.

Schurman, L., McCarthy, A.D., Sedlinsky, C., Gangoiti, M.V., Arnol, V., Bruzzone, L., Cortizo, A.M., 2008. Metformin reverts deleterious effects of advanced glycation end-products (AGEs) on osteoblastic cells. Exp. Clin. Endocrinol. Diabetes $116,333-340$.

Takagi, M., Kasayama, S., Yamamoto, T., Motomura, T., Hashimoto, K., Yamamoto, H., Sato, B., Okada, S., Kishimoto, T., 1997. Advanced glycation endproducts stimulate interleukin- 6 production by human bone-derived cells. J. Bone Miner. Res. 12, 439-446.

Vestergaard, P., Rejnmark, L., Mosekilde, L., 2005. Relative fracture risk in patients with diabetes mellitus, and the impact of insulin and oral antidiabetic medication on relative fracture risk. Diabetologia 48, 1292-1299.

Vlassara, H., Palace, M.R., 2002. Diabetes and advanced glycation endproducts J. Intern. Med. 251, 87-101.

Vlassara, H., Striker, G.E., 2011. AGE restriction in diabetes mellitus: a paradigm shift. Nat. Rev. Endocrinol. 7, 526-539.

Wongdee, K., Charoenphandhu, N., 2011. Osteoporosis in diabetes mellitus: Possible cellular and molecular mechanisms. World J. Diabetes 2, 41-48.

Zhu, L.L., Zaidi, S., Peng, Y., Zhou, H., Moonga, B.S., Blesius, A., Dupin-Roger, I., Zaidi, M., Sun, L., 2007. Induction of a program gene expression during osteoblast differentiation with strontium ranelate. Biochem. Biophys. Res. Commun. 355, 307-311. 